\title{
Remotely Sensed Boro Rice Production Forecasting Using MODIS-NDVI: A Bangladesh Perspective
}

\author{
B.M. Refat Faisal *, Hafizur Rahman, Nur Hossain Sharifee, Nasrin Sultana ${ }^{\circledR}$, \\ Mohammad Imrul Islam and Tofayel Ahammad \\ Bangladesh Space Research and Remote Sensing Organization (SPARRSO), Agargaon, \\ Sher-e-Bangla Nagar Dhaka-1207, Bangladesh \\ * Correspondence: refatfaisal@yahoo.com; Tel.: +880-2914-118
}

Received: 7 March 2019; Accepted: 17 July 2019; Published: 25 July 2019

\begin{abstract}
This research work dealt with the development of an operational methodology with appropriate technical components for monitoring and forecasting of rice crop (Boro) production in Bangladesh. Designed system explores integrated application of remote sensing (RS) sciences and Geographic Information System (GIS) technology. Terra MODIS 16-day Normalized Difference Vegetation Index (NDVI) maximum value composite (MVC) image product MOD13A1 of $500 \mathrm{~m}$ spatial resolution covering Bangladesh have been utilized for a period 2011-2017. Hence the district-wise sum of NDVI on pixel-by-pixel has been calculated from Jan-April during 2011-2017. Regression analysis between district-based pixel-wise summation of MODIS-NDVI and district-wise BBS (Bangladesh Bureau of Statistics) estimated Boro production revealed strong correlation $\left(R^{2}=0.57-0.85\right)$ where in March most of the regression coefficient shows significant correlation due to maximize photosynthetic activities. Therefore, the highest regression coefficient value from derived set of coefficient value (BCP-Boro Crop Production Model 2) has been utilized to obtain year-wise rice productions for all the years (2011-2017). Global Positioning System (GPS)-based field verification, accuracy assessment and validation operation have been carried out at randomly selected geographical positions over the country using various statistical tools. The results demonstrate good agreement between estimated and predicted yearly Boro rice production during 2011-2017 time period with Mean Bias Error (MBE) $=-29,881$ to 19,431 M.Ton; Root Mean Square Error $($ RMSE $)=5238$ to 11,852 M.Ton; Model Efficiency $(\mathrm{ME})=(0.86-0.94)$; Correlation Coefficients $=0.65$ to 0.87 . Therefore MODIS-NDVI based regression model seems to be effective for Boro production forecasting. The system generally appears to be relatively fast, simple, reasonably accurate and suitable for nation-wide crop statistics generation and food security issues.
\end{abstract}

Keywords: Boro Crop; MODIS-NDVI products; ground-based estimates; regression model; forecasting

\section{Introduction}

Rice is one of the most significant agricultural crops in many countries, and it is a primary food source for more than three billion people worldwide [1,2]. The projected global rice consumption is to be 873 million tons in 2030 [3] but the issues of population growth (in particular in the major rice producing/consuming countries) [4] and climate change have created enormous pressure on the global food demand and its production in recent decades [5]. According to [6], climate change will likely increase the exposure of densely populated, low-lying areas to intensified flooding and cyclones consequently and so far Bangladesh experienced 21 above-normal floods, 4 of which were exceptional and 2 catastrophic, since 1954. Moreover, the scientific consensus for the Ganges, Brahmaputra, and Meghna (GBM) rivers basin projected a temperature rise of $1-3{ }^{\circ} \mathrm{C}$ and 20 percent more monsoon 
rainfall by 2050, suggesting that Bangladesh will be exposed to more severe inland flooding [6]. Therefore the impacts of climate change issues may create negative impacts on agricultural yield and production capacity of Bangladesh. Consequently, the changes in rice production and availability can create food crises and food price discrepancy that can be the cause of social troubles due to economic and political changes. Furthermore agricultural statistics has been playing an ever-increasing role in shaping up and providing scientific information that is useful in almost every aspect of human life and beyond. Agriculture statistics is a major concern for the world as a valuable assistance for formulation of appropriate policy and strategic plan in boosting up the food security and rural development. The urgency for an efficient crop forecasting system to provide timely and reasonably accurate crop information in the context of global food security, climate change, production instability etc. is well recognized over the world. Hence, the developing countries like Bangladesh need remote sensing technology-based scientific study for updated crop information such as crop area and yield estimation, crop biophysical property condition, weather conditions, and seasonal characteristics to support early warning decision support systems in order to maintain food sovereignty because of vulnerability to the abrupt climatic changes and frequent natural disasters.

In this regard, the potential application of remote sensing technology for monitoring crop condition and predicting crop yields at regional scales over the past several decades have been studied extensively [7]. The U.S. Department of Agriculture and Directorate General for Agriculture of the European Community have been using Remote Sensing (RS) data to estimate the total production of important crops like rice, wheat etc. [8,9]. The forecasting or prediction of the amount of rice production prior to the end of growing season is crucial in order to ensure food security issues of a country [10-13]. Moreover, the forecasting of rice production statistics can help governments, planners, and decision-makers to formulate appropriate policies in rice importing in the event of shortfall or exporting in the event of surplus as well as purchasing rice earlier at comparatively cheaper rates if other rice-producing countries do not have information about forthcoming need [14]. Thus the reliable forecasts of agricultural commodity production can have significant positive impacts on food security, water resources, and economic stability of a country [15]. Moreover agricultural land area has decreased from 13.3 to 12.17 million ha from 1976 to 2010, with the total loss of 1.11 million ha whereas; cultivatable land area has decreased from $65.75 \%$ in $1976-1977$ to $57.41 \%$ in $2010-2011$ [16]. Noted that the conversion of one landcover to another would directly alter vegetation cover and structure [17] because vegetation and its underlying soil are important factors in global climatic variability [18,19]. Though, the impacts of changes in climate, society, and economy is quite difficult to compute [20] but it is obvious that Bangladesh is facing numerous challenges in terms of rice production estimation and forecasting which are the prime concerns of this research.

Previously several works have been performed to find out the alternate method of remote sensing-based techniques for effective forecasting in rice yield and found strong relationship between satellite-based NDVI with ground-based rice yield for forecasting purpose [11-13,21-24]. Furthermore, the rice crop growth monitoring can be performed by developing regression modeling based on remote sensing images and phenological field data over a period to compare with the past [25,26]. Besides various researchers have also performed relevant researches on the crop production estimates using satellite remote sensing technology and which have been already applied for Pakistan [10] and China [27]. In retrieving agricultural crop information, MODIS constellations [7,28] and MODIS images have been widely used at larger regional scale due to its faster re-visit time ( $\sim 1$ day) and comparatively smaller datasets (memory size or data volume) resulting from its lower resolution [20,29-33].

In Bangladesh, for yield/production information, the Bangladesh Bureau of Statistics (BBS) collects data across the country. Notwithstanding the accuracy of these data and its ability to illustrate historical trends, this method has two major drawbacks: (i) time-consuming, subjective, costly, and labor-intensive [34-36]; and (ii) the results are usually made available to the government, planners, and decision makers after several months of harvesting of the crop; thus become inconvenient for food security purposes $[13,14,37]$. 
Previously, very few works on remote sensing based crop yield forecasting systems have been performed in the context of Bangladesh for example: (i) $[23,24]$ observed that modeled and ground-based rice yield revealed a $\mathrm{R}^{2}$ of 0.56 and 0.89 for Aus and Aman respectively over Bangladesh; (ii) [38] have found high $\mathrm{R}^{2}$ of $0.84,0.72$, and 0.80 for the NDVI, LAI and fPAR, respectively between the regression model of vegetation index and field level potato yield at Munshiganj District of Bangladesh; (iii) [39] found good resemblance between forecasted (i.e., MODIS-based) and ground-based Boro rice yield i.e., $\mathrm{R}^{2}$ (0.76 and 0.86); RMSE (0.21 and $\left.0.29 \mathrm{Mton} / \mathrm{ha}\right)$, and RE ( $-5.45 \%$ and $6.65 \%$ ) over Bangladesh. Moreover various geo-bio-environmental factors such as climate change consequences, increased natural disasters, uncertainty in geo-environmental variability appear to be as possible factors determining the crop production to ensure nation-wide food security in this area. The reason behind the selection of MODIS NDVI products is that the NDVI dynamics is representative of crop growth and biomass changes and is closely connected to crop yield and has direct correlation with LAI, biomass and vegetation cover [40-44]. Hence, the present research has been initiated to develop a Boro crop production forecasting model based on MODIS-NDVI products at country scale. In dense forest canopies, the Normalized Difference Vegetation Index (NDVI) shows saturation effects [11] nevertheless because of the data accessibility and its robustness against noise and varying illumination geometries it is widely-used indices for this purpose [10,12].

The present study is focused on NDVI because it is widely used in phenological works [45-47] and is known to be more sensitive to small increases in the amount of photosynthetic vegetation $[48,49]$. In view of the above, the objectives of this research are: (a) to develop an effective methodological framework to retrieve useful information on seasonal crop and (b) to forecast the seasonal crop production estimates based on the developed methodology for potential use in country's national food security issues.

\section{Materials and Methods}

\subsection{Study Area}

The present study area is located between $20^{\circ} 34^{\prime}$ to $26^{\circ} 38^{\prime}$ North latitude and $88^{\circ} 01^{\prime}$ to $92^{\circ} 42^{\prime}$ East longitude except the three hilly districts namely Rangamati, Khagrachari, and Bandarban (Figure 1). The hilly areas have been excluded from this study because the influence of topographical variations in delineating rice areas have been stated by several studies as the surface reflectance from the hilly terrain might be influenced by the adjacent areas [31,32,50,51]. Moreover most of the areas under these three districts are hilly areas where cultivation of Boro rice is extremely limited and are mainly covered by forests and trees. Bangladesh is bordered by India on the west, north, and east, by Myanmar on the south-east, and by the Bay of Bengal on the south. The country's topography is extremely low and flat, with two-thirds of its land area less than $5 \mathrm{~m}$ above sea level. However, in some place land elevation levels reach up to $25 \mathrm{~m}$ higher than the adjoining floodplains, whereas the tertiary hills (northern and eastern borders) have higher elevation, some reaching over $1000 \mathrm{~m}$ above mean sea level (MSL) [6]. The country has humid, warm, tropical climate which is influenced predominantly by monsoon (June to early-October) and partly by pre-monsoon (March to May) and post-monsoon (late-October to November) flows [52]. The mean annual rainfall is about $2300 \mathrm{~mm}$ whereas annual rainfall ranges from $1200 \mathrm{~mm}$ in the extreme west to over $5000 \mathrm{~mm}$ in the east and north-east, however generally the eastern parts of the country enjoy higher rainfall than the western parts [53]. Regardless of some changeability in climatic conditions (in terms of both temperature and rainfall) the Boro cultivation primarily depends on the groundwater-based irrigation schemes, besides frequent natural disaster like flood, cyclone, drought, river erosion, etc. plays important role in the agricultural productivity [14]. 


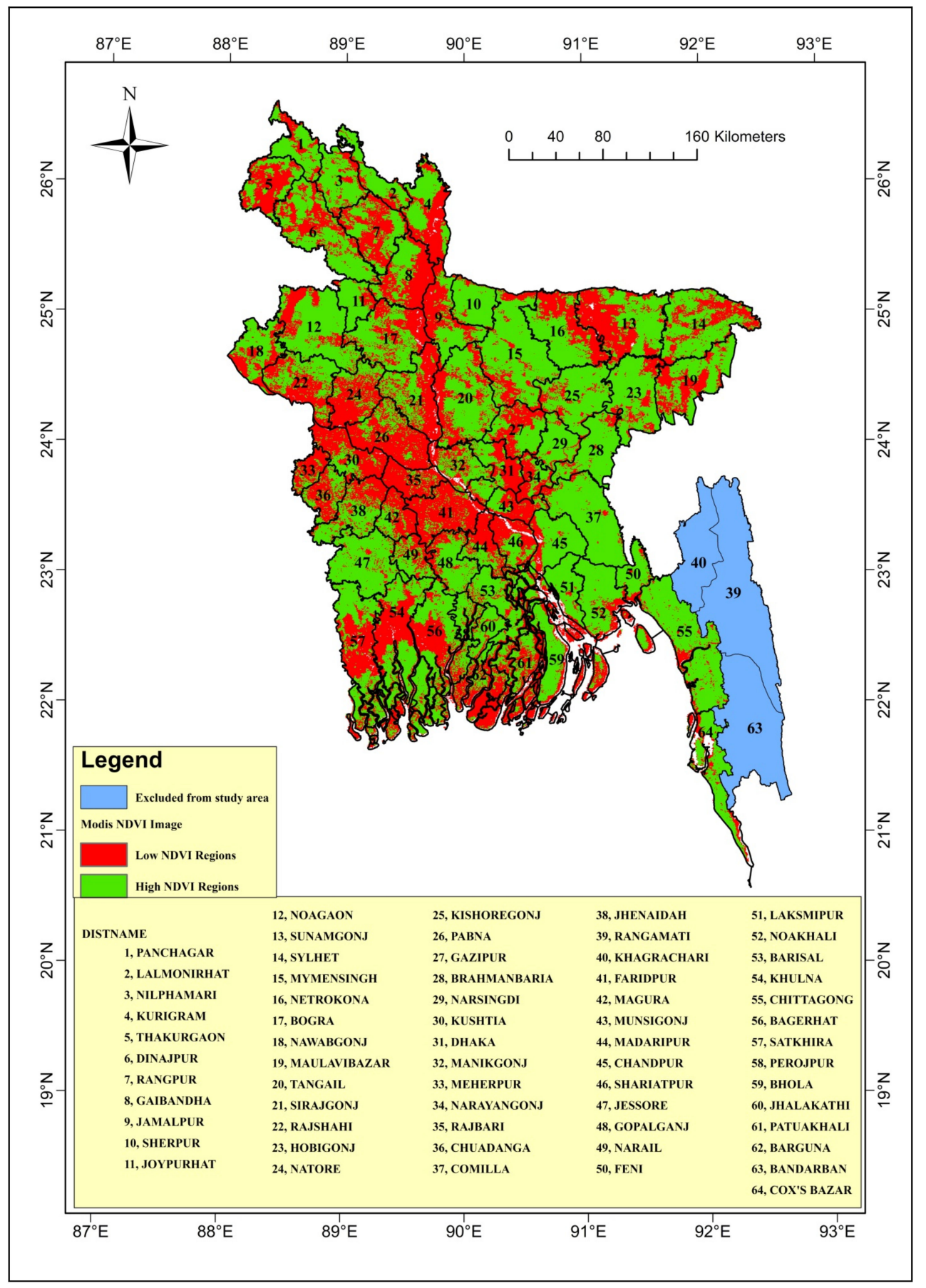

Figure 1. Map showing the sample MODIS imagery over the study area.

\subsection{Rice Information}

For over half of the world's population Rice (Oryza sativa L.) is a staple food. Rice is grown on approximately 146 million hectares, more than 10 percent of total available land [54]. About 535 million tons of un-milled or rough rice (paddy) is produced in total in the world, with ninety seven percent (97\%) of the world's rice grown by less-developed countries, mostly in Asia [55]. Bangladesh is the 4th top rice producing country in the world [55]. The crop phenology over the entire lifecycle of a crop brings important systematic changes in terms of both the architectural and radiative properties of crop 
canopy. Accordingly, crop radiative responses undergo significant changes over the crop life cycle starting from cultivation stage to senescent stages.

However, phenology plays a dominant role in the estimation of vegetation-dependent processes [7]. Research on vegetation phenology uses phenological and spectral ground observation networks, phenological modeling, eddy covariance towers and satellite-derived imagery to assess and monitor vegetation status and dynamics [9]. At the peak or maximum green stage, the value of NDVI becomes maximum because there is maximum chlorophyll in the green crop. However, the NDVI value shows a decreasing value just after this phenological stage and the chlorophyll concentration also decreases. Therefore, attention has to be made to select proper time. At this stage NDVI shows maximum sensitivity to changes in biophysical condition of the rice crop under observation. Hence the Boro crop phenology has been given in Table 1.

Table 1. Phenology of Boro rice in Northwestern Bangladesh.

\begin{tabular}{ccccc}
\hline \multicolumn{5}{c}{ Stage s (Days) } \\
\hline Initial & Vegetative & Flowering & Maturing & Total \\
\hline 25 & 60 & 40 & 20 & 145 \\
1st Jan-25th January & 26th Jan-25th March & 26th March-5th May & 6th May-25th May & January-May \\
\hline
\end{tabular}

\subsection{Geospatial Data Requirements}

To meet the objectives of this research two MOD13A1 scenes (MOD13A1: h25v06 and h26v06) have been freely accessed from US National Aeronautical Space Agency (NASA) Earth Observing System (EOS) website in Hierarchical Data Format-Earth Observing System (HDF-EOS) format to cover the study area for each date studied [57]. The MOD13A1 version 6 products have been selected because the algorithm for this product chooses the best available pixel value from all the acquisitions from the 16 day period with low clouds, low view angle, and the highest NDVI/EVI value [58]. Among the MODIS VI products, the NDVI is chlorophyll sensitive whereas the EVI is more responsive to canopy structural variations, including leaf area index (LAI), canopy type, plant physiognomy, and canopy architecture [59,60]. Terra MODIS 16-day maximum value composite (MVC) NDVI image products (MOD13A1) of $500 \mathrm{~m}$ resolution have been utilized for the present study to develop an effective methodology to obtain crop information and forecasting of Boro crop production in Bangladesh. Data coverage for each month from January to April time period covering Boro life cycle during 2011 to 2017 have been utilized. Ultimately, each image corresponding to each month as obtained is based on the selection of the best pixel value from a total of 16 images of 16 consecutive dates of the same pixel.

For the present study, Bangladesh Bureau of Statistics (BBS) estimated Boro rice crop production statistics during 2011-2017 were collected. For yield/production estimation information, BBS followed the Food and Agriculture Organization (FAO) guided conventional methods (direct observation and measurement) and collects data from 10,348 numbers of clusters where each cluster constituted 5 acres of land on an average throughout the country as sample frame. Besides a well-defined crop calendar is followed to collect data in the field level throughout the year. The cluster has been formed from cadestral plot listed in the land records of Bangladesh and are allocated among the districts proportionately to the size of the district with restriction that the number of cluster in a district should be at least 150 . Then for each cluster, the sample crop cutting method for Boro rice was used where a circular cut of total area 215.278 sq. $\mathrm{ft}$. (20 sq meters) with a radius of $8.278 \mathrm{ft}$ was considered. For the crop estimation reporting system, the selected sample clusters were visited four times in a year and crop-cutting experiments were conducted in due time to estimate the rice crop production of Bangladesh. Finally, the yield rate was calculated and multiplied by the district area to find out the production estimate for each district therefore the country level estimates qwre obtained by summing up the estimates of districts [61]. According to the FAO guideline, the structural agricultural statistics of BBS were generated by collecting data through full 
count/sample census normally at a regular interval of ten years, whereas the annual agricultural statistics were generated through annual/periodic sample surveys [62].

\subsection{Normalized Difference Vegetation Index (NDVI)}

NDVI, calculated as the difference between near-infrared and visible reflectance values normalized over the sum of the two [63], was anticipated as a means to estimate landscape patterns of productivity. But forest vegetation and homestead vegetation both contributed to the NDVI calculation. However, increasing vegetation density enhanced the NDVI values for a given crop area, whereas decreasing vegetation gave rise to reduced NDVI values over evolving crops and other surface features.

\subsection{Maximum Value Composite (MVC) at MODIS VI Products (MOD13A1)}

The MODIS VI products (MOD13A1) applied the maximum value compositing (MVC) technique to derive NDVI over a time period of 16 days for each observation. This data product utilized MVC technique to process MODIS data on a pixel-by-pixel basis for each from a total of 16 daily time series data value [64]. Eventually, the MVC approach enabled the users to obtain pixel-by-pixel cloud-free, quality images representing major changes in the crop properties, condition, as well development and growth of growing Boro crop at different stages of development during the Boro lifecycle. Furthermore the composite algorithm utilized the information in the reflectance quality assurance (QA) flags, particularly those derived from the MODIS cloud mask product, to preprocess the atmospherically corrected reflectance data of MODIS Bands 1-3, and 7 (red, NIR, blue, MIR) over land only where the land pixels with clouds, shadow, and bad data integrity were excluded from VI composite [65]. Besides MVC's had the added advantage of reducing the effects of other unwanted influences on the NDVI values (such as atmospheric interference). An MVC NDVI image of the area provided pixel-wise NDVI values indicative of the condition of each pixel under observation. Pixel-wise spatial summation of NDVI values for all the individual pixels covering each individual district area in the MVC NDVI image provided a single value for each district. It has been reported that this MVC data product is known to be able to account for both background and aerosol effects [48,60]. The utility of the maximum value composite Image technique has been tested in a case study to generate NDVI over the Indian Subcontinent. The MVC technique minimized cloud contamination, reduces off-nadir viewing effects, and generated maximum value composite image. It has been widely reported by various researchers that MVC techniques remove most clouds and cloud shadows, offer high spatial coherency, and present middle-to-low sensor zenith angles in time series images. Besides standard NASA MODIS composite provides close to nadir observation angles, and good spatial coherency [66].

\subsection{Digital Overlay and Masking Operation}

In this research work, spatial masking layers played an important role in obtaining information on seasonal crops like Boro rice as the calculated satellite-based NDVI values were influenced by the forests, homestead vegetation, as well as seasonal vegetation other than Boro crop. Digital identification and separation of surface features under different categories of vegetation and non-vegetation is the initial step in this operation. Table 2 provides a list of surface feature categories contributing to the pixel-wise ultimate radiative response values determining the NDVI magnitude of that particular pixel. These feature elements had specific roles in determining the pixel-wise NDVI calculation. At this stage, a spatial masking operation was carried out in the ERDAS Imagine platform using previously prepared vegetation mask layer. In preparing the vegetation mask layers, a number of vegetative surface features were considered. The vegetation mask layer includes (i) forest features, (ii) homestead vegetation together with (iii) seasonal crops, and (iv) mostly non-vegetated soil areas. The purpose of the vegetation mask was to screen out part of vegetation which was mostly stable or having unchanged cover for relatively longer time period. The basic approach consisted of producing a vegetation mask layer to facilitate the process of separating the forest and vegetation layer. Vegetation mask layers were generated from high-resolution satellite data and were utilized to find the district-wise rice pixel only in present study. Regular updating 
of these layers in every $3-4$ years period seemed to be satisfactory to obtain the updated surface features at country scale. The spatial details used moderate high-resolution satellite images with a spatial resolution of $5 \mathrm{~m}$ or so, on which the temporal dynamics of the crop, as demonstrated through NDVI, was taken into account by supplementing with high resolution images with less frequent observation. Some information on the satellite data, along with relevant characteristics/parameters, are given in Table 2. Increasing vegetation density enhanced the NDVI values for a given crop area. While decreasing vegetation gave rise to reducing NDVI values over evolving crops and other surface features. The detailed method of generating and updating spatial vegetation mask layer is illustrated in Figure 2. However, the changes in the mask layer feature (Figure 3a,b) for smaller area coverage (Madhupur tract) are illustrated in Table 3 to show the low variations from the 2011-2017 time period.

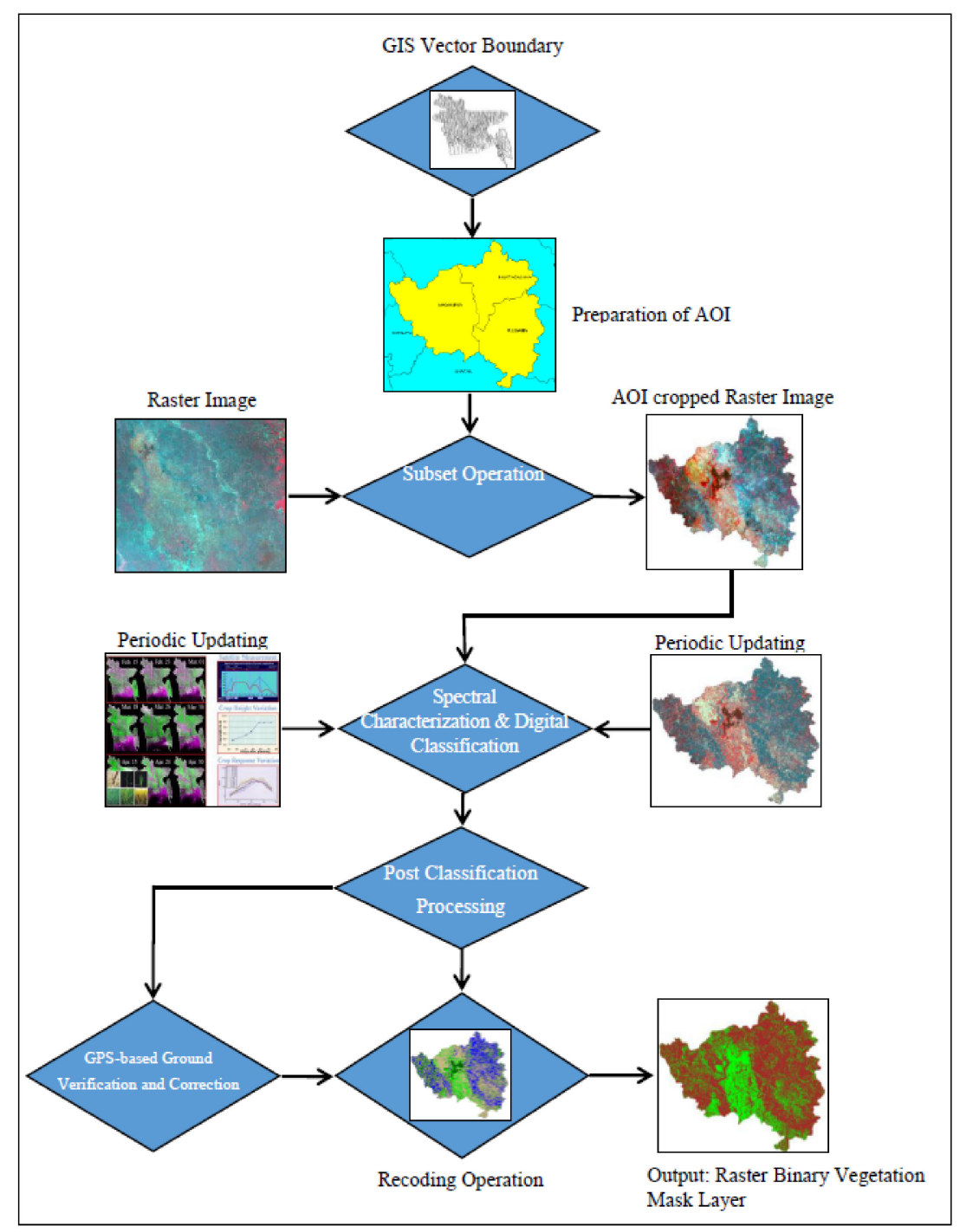

Figure 2. Methods of generating and updating raster binary vegetation mask layer. GIS: Geographic Information System; GPS: Global Positioning System. AOI: Area of Interest 
Table 2. List of major surface features to be monitored along with necessary time interval, spatial resolution, and data source.

\begin{tabular}{cccc}
\hline \multirow{2}{*}{ Feature Category } & \multicolumn{3}{c}{ Preferred Periodic Updating } \\
\cline { 2 - 4 } & Time Interval & Spatial Resolution $(\mathbf{m})$ & Satellite/Sensors \\
\hline Forests & 3 years & $30 / 22$ & Landsat TM/DMC \\
Homestead vegetation & 3 years & 5 & RapidEye \\
Seasonal crop field & Seasonal & 500 & TERRA/AQUA MODIS \\
Seasonal Boro rice & Seasonal & $30 / 22$ & Landsat TM/DMC \\
Non-Vegetated areas & 3 years & 5 & RapidEye \\
\hline
\end{tabular}

Therefore, based on MODIS NDVI raster layer supported by the district GIS boundary layer, a district-wise pixel-to-pixel addition operation was carried out. Such an operation provided an NDVI summation of all the pixels i.e., $\sum_{i=1}^{n} N D V I_{i}$ for each district areas as defined by the GIS district boundary. Here $\mathrm{n}$ is the total number of data points (pixels) under a given district. Ultimately, the derived summed NDVI corresponding to all the pixels within each district area have been prepared and is assumed to be proportional to the presence of vegetation therein.

Table 3. Changes in mask layer feature from (2011-2017) at Madhupur tract.

\begin{tabular}{ccc}
\hline Surface Feature & Area in 2011 (Ha) & Area in 2017 (Ha) \\
\hline Water body & 28,715 & $24,372.9$ \\
Vegetation & $20,079.8$ & $21,480.9$ \\
Crop area & $12,913.6$ & $16,370.8$ \\
Others & $61,563.4$ & $61,050.4$ \\
\hline
\end{tabular}

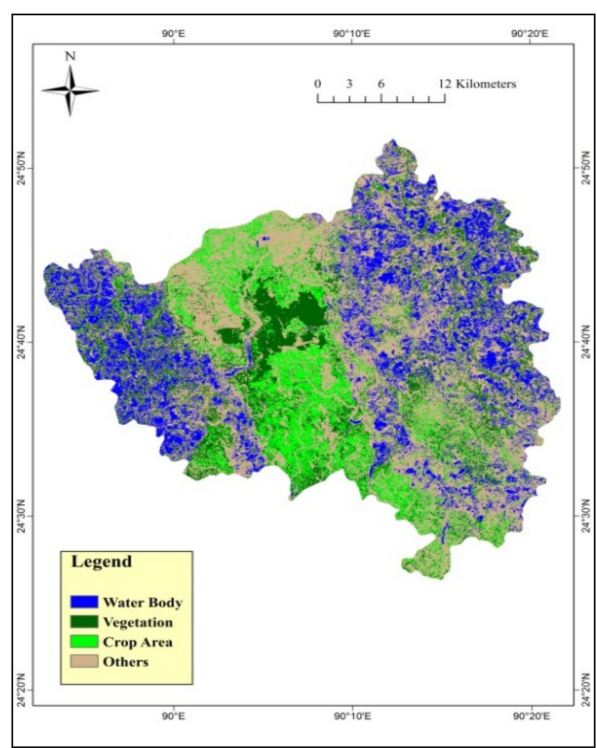

(a)

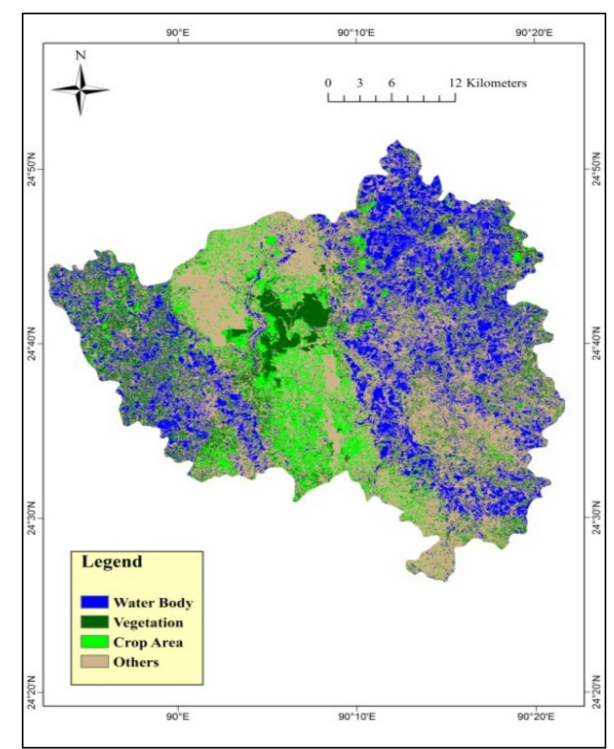

(b)

Figure 3. (a) Mask layer properties in 2011, (b) Changes of mask layer properties in 2017.

\subsection{Spatial Resolution and Information Precision}

The precise crop information relatively depends on the classification accuracies of different surface features which are influenced by spatial resolution, window size, texture extraction, and spatial structure. In the present study, the major surface features-likely forests, homestead vegetation, seasonal crop field, seasonal Boro rice, and non-vegetated areas-were generated considering spatiotemporal characteristics to monitor the changes of surface features at specific time intervals. However, for more heterogeneous or fragmented landscapes, finer resolution, and larger window size were required, 
whereas a small window was preferable to improve the classification accuracy of different surface features for spectrally homogeneous classes [67]. Therefore, in this study relatively slowly growing vegetation features were generated from high resolution optical images and moderate high-resolution satellite image with spatial resolution of $5 \mathrm{~m}$ or so were used for spatial details. A GPS-based field verification campaign was conducted to verify the accuracy of the retrieved information using the technique in identifying the feature type. However, the temporal dynamics of the crop were taken into account through supplementary high-resolution images with less frequent observation. The image classification accuracy was affected by boundary pixel, and finer spatial resolution increased the spectral-radiometric variation of land cover types [68], whereas $[69,70]$ evaluated that the impact of resolution change is greater than the change of aggregation level on the information context and classification accuracy. Hence the present study duly considered the temporal dynamic and spatial heterogeneity characteristics in surface feature identification and masking operations with continuous time intervals for regular updating (Table 2) for precise crop information.

The accuracy of the generated information was checked considering positions of randomly distributed points. The whole process of verification was guided by Global Positioning System (GPS). Verification positions included relatively distinct surface features under categories of vegetation, ponds, and roads verifying positional accuracies. Identification of class category was also checked showing positional accuracy of about $10 \mathrm{~m}$ for the surface features. It was observed that forest and homestead vegetation covers generally exhibited relatively high NDVI values. Considering the flattening (saturation) characteristics of NDVI curve, these categories of surface features are being separated digitally using high resolution satellite images on a regular time interval of 2-3 years in order to facilitate the information retrieval processes and to reduce possible interclass conflicts due to flattened NDVI-curve for high NDVI values. Feature-based analysis of radiometric responses in different spectral bands showed relatively high response values over the forests and homestead vegetation areas. In order to reduce anomalies in feature identification using spectral signatures, optimum timing was considered based on the crop calendar of the area. A carefully-selected time period for obtaining the forests and homestead vegetation areas with minimum conflicts and overlapping with other co-existing vegetation was selected over a time period when transition (gap) between two crop seasons occurred particularly around (i) the harvesting period and subsequently (ii) the plantation period.

\subsection{Methodological Framework}

A comprehensive methodological step for this study has been illustrated in Figure 4. After acquisition of these satellite images, multiple steps of pre-processing were performed to develop rice production forecasting methods, likely (a) conversion of HDF format dataset into image compatible format through (MODIS Conversion Tool-kit) MCTK and ENVI software; (b) re-projection of the NDVI images into Transverse Mercator; (c) necessary geometric correction; and (d) digital mosaicking of the collected images (MOD13A1: $\mathrm{h} 25 \mathrm{v} 06$ and h26v06). The geometric and geo-referencing operations of Landsat TM imageries of the study area to ensure proper geometric matching of different surface features in time series images were performed using Ground Control Points (GCP) of the area as collected by the ground truth team of SPARRSO using Global Positioning System (GPS) by following standard methodology as available in ERDAS Imagine Image Processing software [71]. Besides, the MODIS VI products (MOD13A1) was atmospherically corrected and modified by MVC techniques which addressed the atmospheric perturbation.

Therefore, after necessary pre-processing of satellite imageries, the country scale vegetation layer was used to mask out the non-crop vegetation cluster to consider the rice pixel only hence the district-specific sum of NDVI values has been extracted from January to April at respective years. After that, regression analysis was performed between MODIS derive district wise sum of MODIS-NDVI values with ground-based (BBS estimated) rice crop production statistics over the period of 2011-2017. As a fundamental approach, the model coefficients were derived through mathematical optimization of the functional model against a given data set covering a given time period 2011-2017. Then, based on the highest regression coefficient value, the regression model of March 2014 has been 
applied to independently generate crop production data values at the country scale from the years 2011-2017. After that, the comparison was made with the RS model-based simulated results versus ground-based BBS estimated crop production statistics for testing or validating the model which were not used to retrieve the values of the parameters. Where the statistical parameters like (a) Mean Bias Error (MBE); (b) Root Mean Square Error (RMSE); (c) Model Efficiency (ME) have been derived for accuracy assessment by applying the Equations (1)-(3).

$$
\begin{gathered}
\text { MBE }=\frac{\sum_{i=1}^{n}\left(P_{i}-O_{i}\right)}{\mathrm{n}} \\
\mathrm{RMSE}=\sqrt{\frac{\sum_{\mathrm{i}=1}^{\mathrm{n}}\left(\mathrm{O}_{\mathrm{i}}-\mathrm{P}_{\mathrm{i}}\right)^{2}}{\mathrm{n}}} \\
\mathrm{ME}=\frac{\left.\left.\left[\sum_{I=1}^{n} \mathrm{O}_{\mathrm{i}}-\bar{O}\right)^{2}-\sum_{I=1}^{n} \mathrm{P}_{\mathrm{i}}-\mathrm{O}_{i}\right)^{2}\right]}{\left.\left[\sum_{I=1}^{n} \mathrm{O}_{\mathrm{i}}-\bar{O}\right)^{2}\right]}
\end{gathered}
$$

where $\mathrm{n}$ is the number of data points, $\mathrm{Pi}$ is the $\mathrm{i}^{\prime}$ th model predicted data point, $\mathrm{O}_{\mathrm{i}}$ is the $\mathrm{i}^{\prime}$ th observed data, and $\mathrm{O}^{-}$is the mean of observed data.

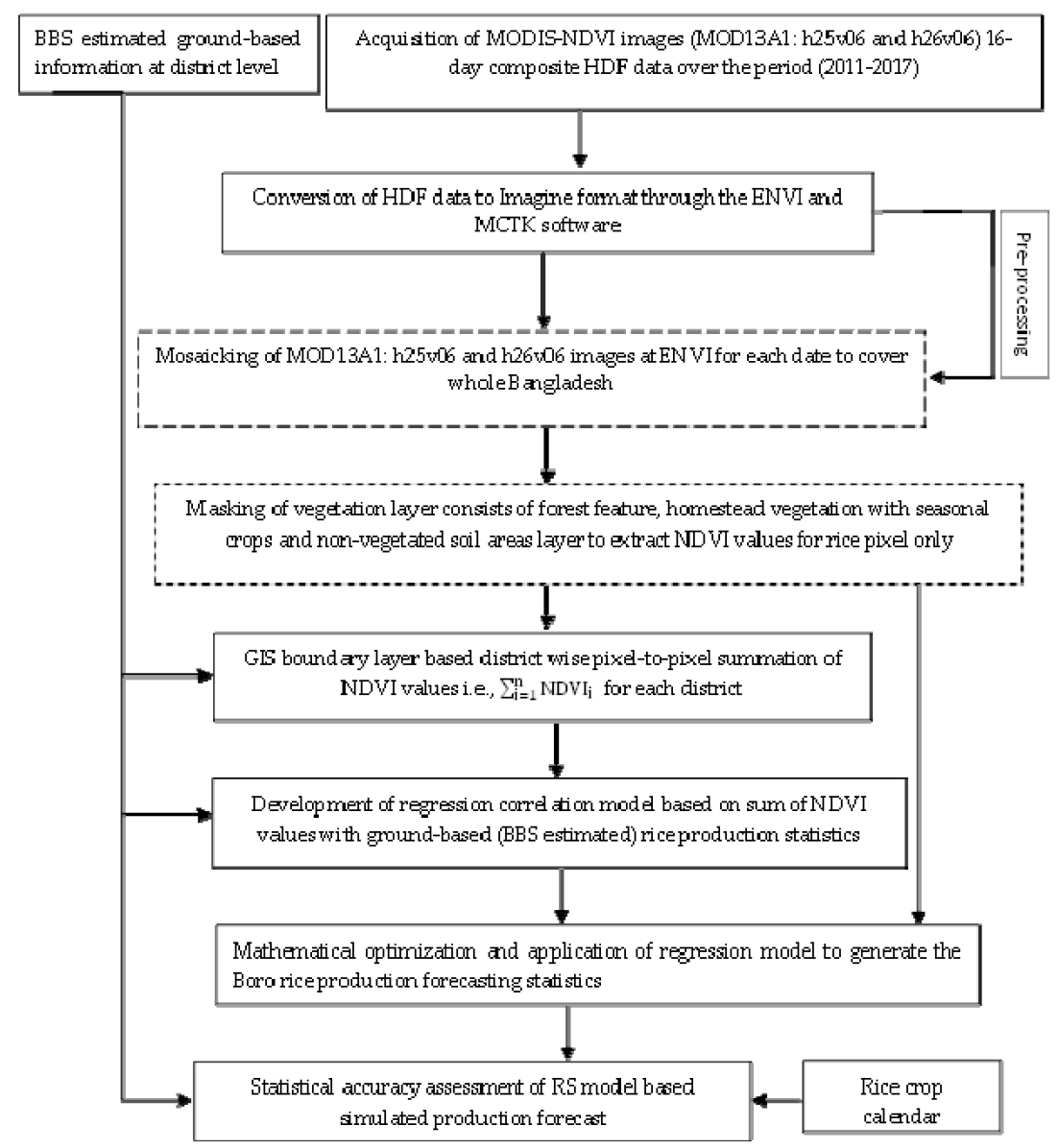

Figure 4. Schematic diagram of remotely sensed Boro rice production forecasting methodology. RS: Remote Sensing; NVDI: Normalized Difference Vegetation Index; BBS: Bangladesh Bureau of Statistics; MCTK: Modis Conversion Toolkit. 


\section{Results}

The following section of this research will chronologically describe the present study outcome with some recommendations for future study.

\subsection{Development of Remotely-Sensed Boro Rice Production Model}

Various studies have found the potentiality of a regression model derived from remote sensing based NDVI and ground-based crop statistics to estimate the crop yield [38,72,73] and crop production [74] under different management condition with reasonable validity $[75,76]$. Boro season in Bangladesh generally continues from January to April where transplantation begins in January and the crops become mature at the end of March. Maximum NDVI values are attained during peak greenness period around 3rd-4th week of March. Hence linear regression model based on the relationship between the sum of MODIS-NDVI and the ground-based (BBS estimated) crop production from January to April during 2011-2017 have been developed and stated in Table A1 with the determination of coefficient. Accordingly, regression coefficient shows highest regression value in March among the entire regression coefficient. The regression coefficient value ranges from (0.57-0.85) among the individually developed twenty-eight (28) regression coefficient. The lowest and highest regression coefficient value of $R^{2}=0.57$ and $R^{2}=0.85$ were found in April 2012 and March 2014 respectively. The reason for this is that the peak greenness periods represent the highest NDVI values $[29,77,78]$ and March 23/24 to April 6/7 depending on leap year has been considered as a peak greenness period in the context of Bangladesh [14,23,24]. Some other articles [29,78-81] also support these findings that the peak greenness period (March) is generally related to the Boro crop production.

The regression coefficient during (2011-2017) shows strong positive relationships that are similar to other studies [82]. This coefficient value from individually developed twenty-eight (28) regression model shows the strength of the model in representing the bound variables of the independent variable. Regression equation depicts that, there is a distinctive relation between Boro rice crop productions with sum of MODIS-NDVI values which may mean that the increases in sum of MODIS-NDVI during the peak greenness period is generally related to the Boro crop production. Figure 5 demonstrates time series graph showing $\mathrm{R}^{2}$ in $\mathrm{Y}$-axis and months (Jan-April) in $\mathrm{X}$-axis for seven years regression line (2011-2017).

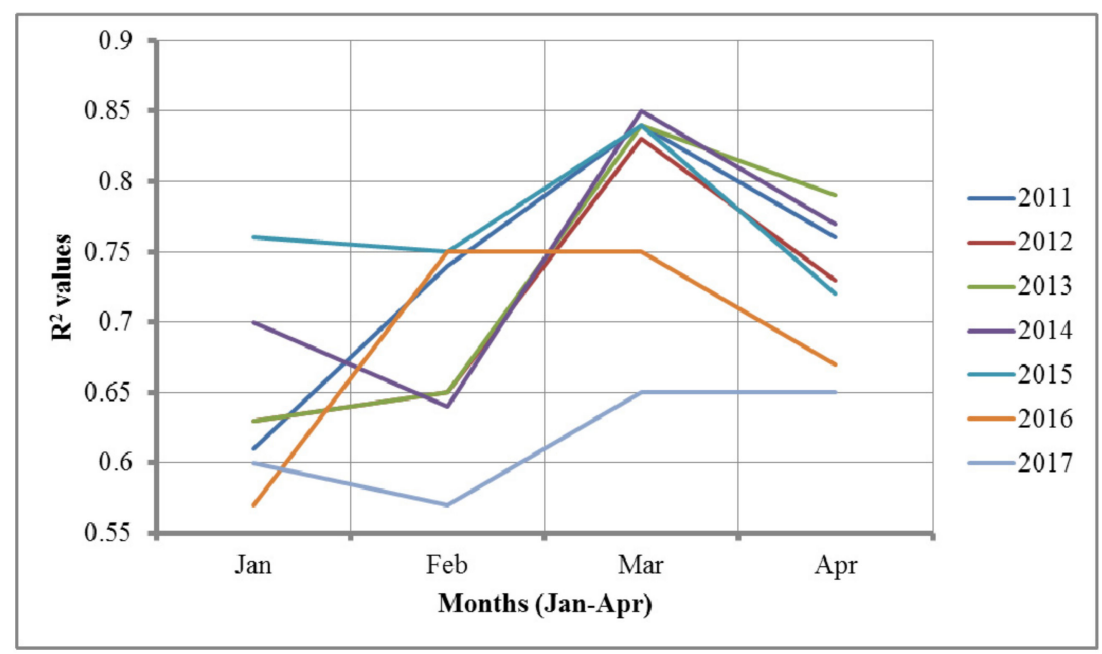

Figure 5. Monthly scale variations of remote sensing regression models (2011-2017).

Hence, based on the highest regression coefficient, month-wise regression models have been derived to simulate the Boro crop production like for the month of Jan-Feb; BCP Model-1 can be used whereas BCP Model-2 and BCP Model-3 are applicable for March and April respectively. Hereafter the 
forecasting of Boro rice production as a function of the sum of MODIS-NDVI values can be described by the following relationship:

$$
\begin{aligned}
(\mathrm{Jan} / \mathrm{Feb}) \text { Boro Crop Production }(\mathrm{BCP})_{(\mathrm{M} . \mathrm{Ton})} & =0.5238 \times \sigma-82419(\mathrm{BCP} \text { Model }-1) \\
(\text { March }) \text { Boro Crop Production }(\mathrm{BCP})_{(\mathrm{M} . \text { Ton })} & =0.4368 \times \sigma-62650(\mathrm{BCP} \text { Model }-2) \\
(\text { April }) \text { Boro Crop Production }(\mathrm{BCP})_{(\mathrm{M} . \text { Ton })} & =0.437 \times \sigma-57214(\mathrm{BCP} \text { Model }-3)
\end{aligned}
$$

where, the dependent variable (BCP) has been expressed in absolute values (M.Tons) for each district, 0.5238 and 82,$419 ; 0.4368$ and 62,$650 ; 0.437$ and 57,214 are the regression coefficients, and $\sigma$ is the sum of NDVI values for each district.

\subsection{Simulation of Remotely Sensed Rice Production Model}

Therefore, the remote sensing regression model (BCP Model: 1-3) with derived coefficients have been applied to simulate the Boro crop production for each of the other individual years during 2011-2017 but, as expected, the difference between the predicted and the estimated production becomes higher than the regression model of BCP Model-2. Because high NDVI values indicates enhanced photosynthetic activities approaching towards peak growth stage of the rice crop around March. Moreover, other RS-derived regression models can be used also but in the context of Bangladesh the BCP Model-2 is more applicable and suitable because of the peak greenness period during March. Hence, simulation results of the regression model (BCP Model-2) were summarized over the 2011-2017 period in this section. Coefficients values of the regression model were derived through mathematical optimization of the model against a single year data of 2014. Then using the same set of derived model coefficient values (that of the year 2014), data for the other year 2011-2017 were generated independently. So that for training the model, only one year was utilized and the remaining years have been evaluated. Table A2 provides statistics on Boro rice production for the years 2011-2017 according to the SPARRSO RS Model-based estimation along with ground-based BBS estimation using sampling and crop cutting following FAO guideline. Statistics as derived from RS Model-based observation vs. BBS estimated production (Table A2) show a relatively high correlation $\left(R^{2}\right)$ values from about 0.65 to 0.87 for all the years from 2011-2017. It is noted that a greater signal to noise ratio offers greater possibility to obtain better accuracy in production estimation. The differences between the predicted values and the official statistical values demonstrate the potential of a remotely sensed MODIS-NDVI based Boro rice production estimate at country level. Various studies relevant to the crop yield forecasting notably $[12,37,77,80]$ have also found good agreement between the estimated and predicted rice yield in different countries. Then statistical measures like MBE, RMSE, and ME were employed to analyze the suitability of the developed model [83].

\subsection{Accuracy Assessment of Boro Rice Production Model}

Finally, the accuracy assessment of the Boro production forecasting model was performed with statistical tools (Equations (1)-(3)) described mathematically by [84] which was used in relevant studies [83]. The regression model based estimated crop statistics from BCP Model-2 during 2011-2017 was assessed with statistical parameters MBE and RMSE presented in Figure 6. Besides, Figure 7 also reveals strong relationships between the predicted and estimated value for the Boro crop in Bangladesh as the $\mathrm{R}^{2}$ value at yearly scale ranges from $0.64-0.85$ over 2011-2017. The MBE for the applied Boro forecasting model ranges from $(-29,881$ to 19,431$)$ M.Ton which reveals that the applied model underestimates the Boro production in 2012, 2013, 2015, and 2016 whereas the overestimation have been found in 2011, 2014, and 2017 as the positive MBE gives the average amount of overestimation in the calculated value and vice versa [84]. The RMSE value for the applied model ranges from $(5238-11,852)$ M.Ton, which is a positive value and also the use of RMSE in model validation has been appreciated by $[83,85]$. Model Efficiency (ME) is used to assess the potentiality of the model and in this study 
the ME ranges from (0.86-0.94) for the applied Boro crop forecasting model. The relevant literature suggests that an ME of 1 is a perfect match of modeled data to the forecasted data and essentiality the closer the ME is to 1, the more accurate the model is [86]. Hence the present ME over the period of (2011-2017) shows potentiality for using this model for Boro crop production forecasting at country scale. Therefore, the MBE, RMSE, and ME values in this study indicate close prediction results for Boro crop forecasting estimates during 2011-2017 for Bangladesh (Table A2). Regardless of strong relationship between the forecasted and estimated Boro production, it would be meaningful to note that the model-based forecasting may be affected by unexpected weather condition $[86,87]$.

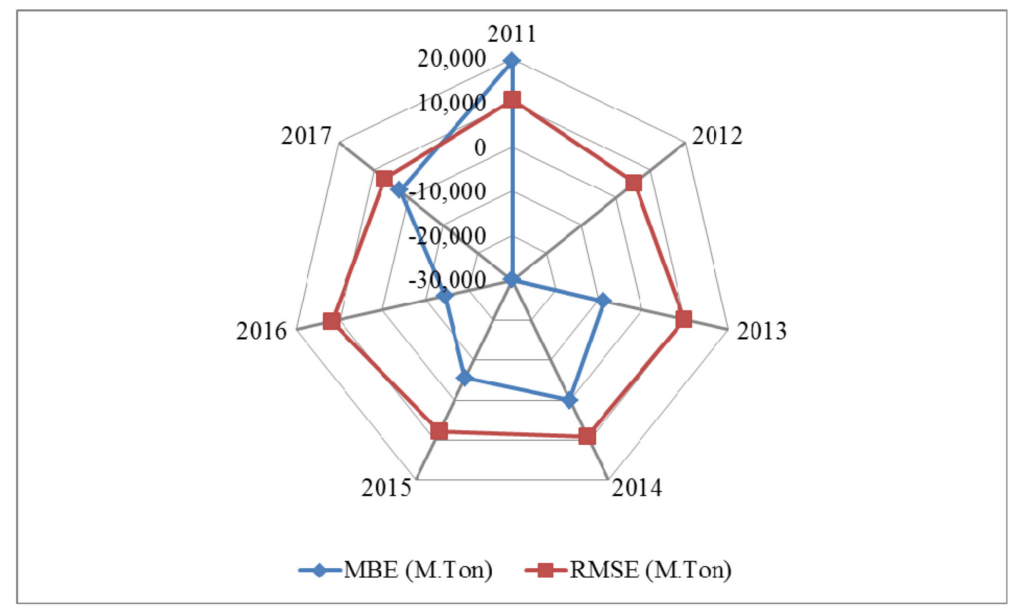

Figure 6. Radar chart showing statistical accuracy of RS model simulation for each year. RMSE: Root Mean Square Error; MBE: Mean Bias Error.

Nevertheless, these error rates at the potential relationship between the sum of MODIS-NDVIs and estimated Boro rice production may be found due to the presence of cloud [88] and atmospheric-moisture contamination in the NDVI signals as well as some methodological errors in the ground-based data collection procedure due to field data collection procedure and data entry, delays in data accumulation to the office, and delivery due to natural disasters like flood, drought, and cyclone. [89,90]. However, the fragmented landscapes [86], average small farm size (0.24 hectares), and heterogeneous characteristics of Bangladesh may create some irregularity in the predicted model [91]. Besides the ground-based and forecasted rice production estimates could be attributed by other factors, such as the quality of acquired satellite data [85]; climate variability over the seasons [13,89]; and ambiguity associated with ground-based estimates [39].

Based on the statistical parameters $\mathrm{R}^{2}$, RMSE, and RE, as well as graphic inspection of the agreement between the production reported by ground-based estimates of BBS and the remotely sensed products, we can summarize that the remote sensing-derived Boro rice-cropped production can be predicted from MODIS-NDVI based regression model. The proposed model provides a flexible way of generating Boro crop production statistics at country scale in heterogeneous landscape of Bangladesh as the model shows promising results though there may have some limitations in its present form but there are ways to improve in the future implications. The satellite-derived estimates also have drawbacks such as dependency on the availability of NDVI images, image processing and analysis error, and calibration error. On the other hand, pixel-level interpretation and imagining is challenging because of low-resolution biasness of MODIS data in field observation and heterogeneity of cropping systems to detect crop phenological changes [92]. Henceforth, the investigation of vital weather parameters such as temperature, precipitation, and solar radiation in particular, as all these issues play an important role in terms of forecasting model-based crop production statistics [93]. Moreover, the developed satellite remote sensing-based model needs to be assessed prior to implementing in other geographical locations. 


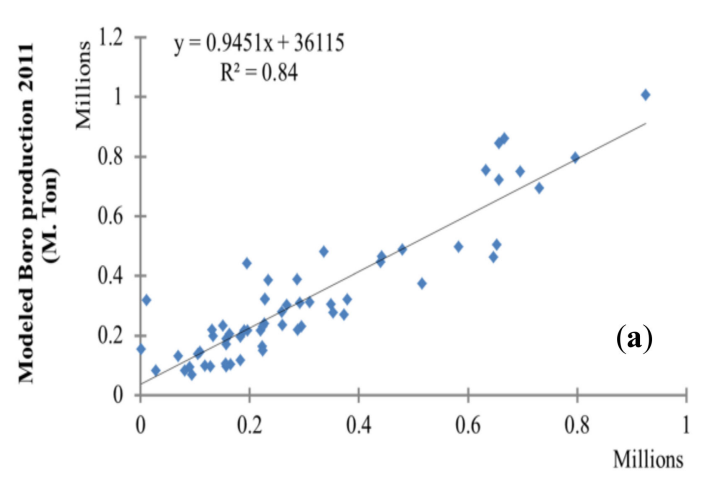

BBS estimated Boro production 2011 (M.Ton)

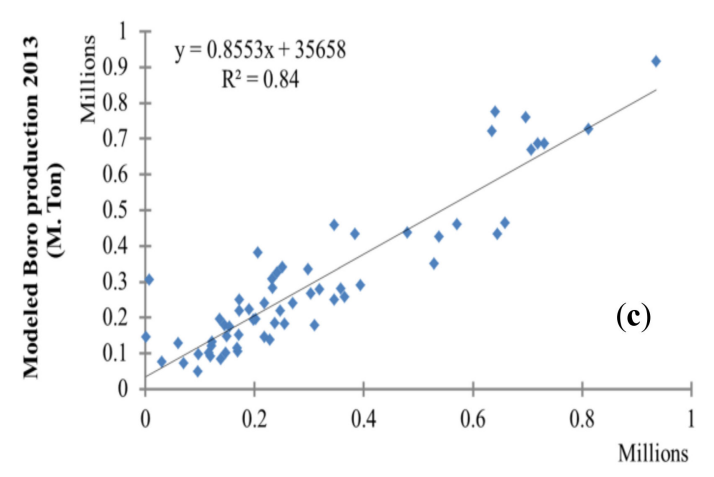

BBS estimated Boro production 2013 (M.Ton)

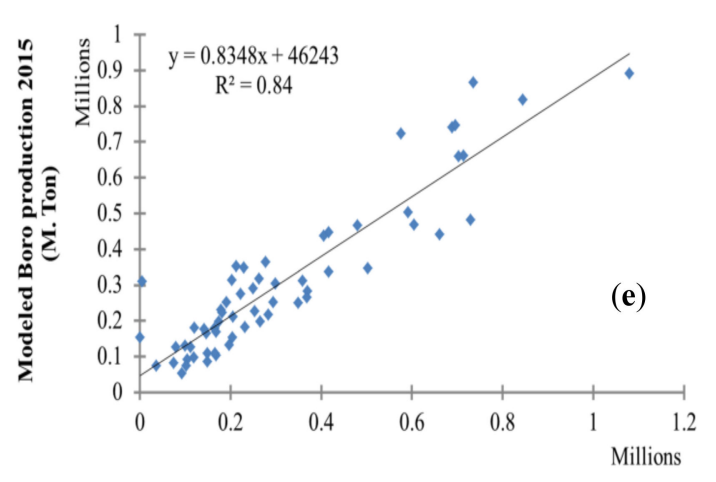

BBS estimated Boro production 2015 (M.Ton)

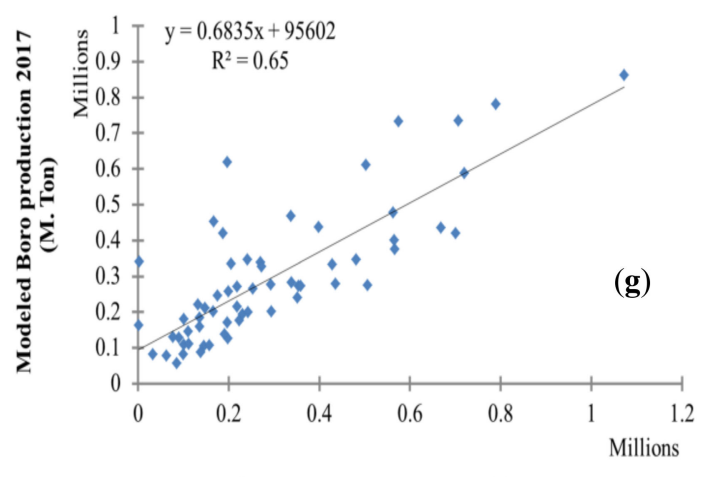

BBS estimated Boro production 2017 (M.Ton)

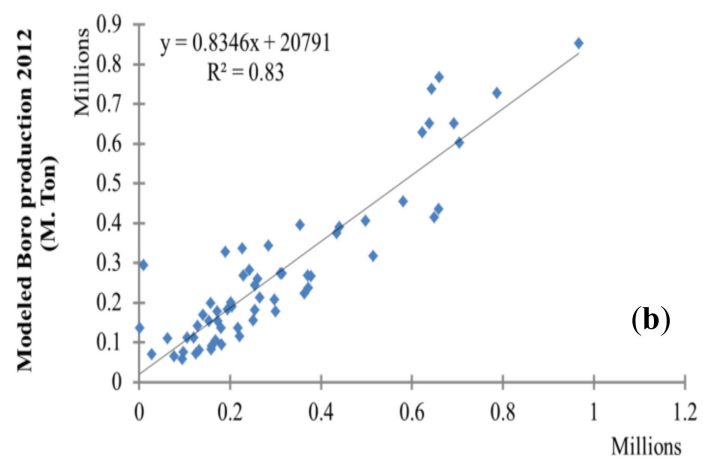

BBS estimated Boro production 2012 (M.Ton)

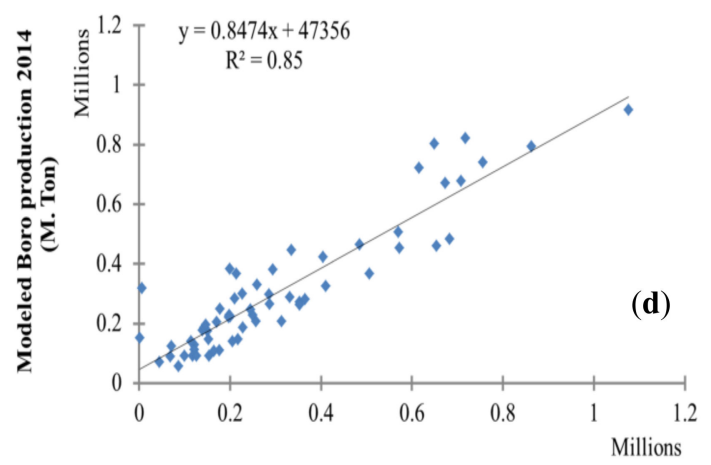

BBS estimated Boro production 2014 (M.Ton)

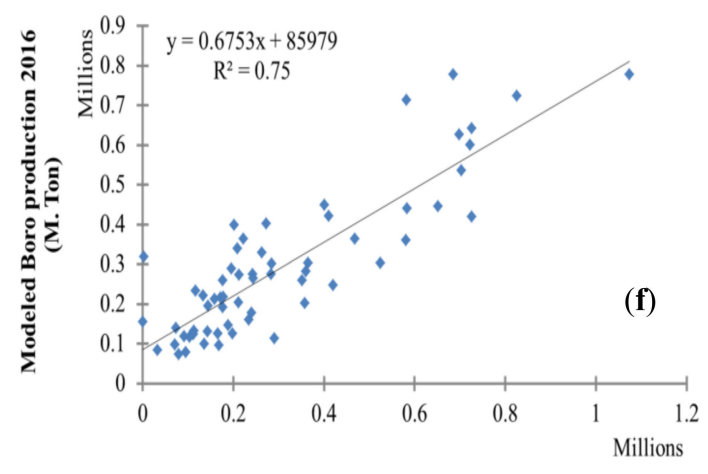

BBS estimated Boro production 2016 (M.Ton)

Figure 7. Relationship between model-based forecasted and ground-based (BBS estimated) production estimates at 61 district-levels during (a) 2011; (b) 2012; (c) 2013; (d) 2014; (e) 2015; (f) 2016; and (g) 2017. 


\section{Conclusions}

The urgency for an effective rice crop estimation system is well-recognized under threats of climate change phenomena with increased natural disasters the world over. The full potentiality of satellite remote sensing and GIS is to be properly exploited for different application areas including food security. Climate change phenomena influencing various meteorological parameters and thereby introduce uncertainties in rice crop production. This research work concentrates on the development of an effective and easy to use technical system to forecast the rice production in advance where MODIS-MVC data product particularly MOD13A1 seems to be useful in such purpose. Time series analysis and preparation of data through maximum value compositing technique seems to be suitable. The methodology directly estimates the district-wise rice production from pixel-by-pixel NDVI summation calculation. The sum of NDVI within a district area on pixel-by-pixel provides direct estimation of the district-wise rice production. The methods used in this study allows predicting Boro crop production before harvesting time though the district level NDVI value shows variability due to regional geo-morphological unevenness over the country. The variation due to cloud coverage and aerosol and Rayleigh scattering has been minimized through pixel-by-pixel selection of pixels for maximum value of NDVI. Findings suggest that the MODIS-NDVI-based regression models could be best suited as the estimated and predicted crop productions have resemblance to crop statistics with reasonable statistical validity. Furthermore, model validation provides an indication of the reasonable levels of model accuracy and reliability. However, more empirical studies need to be performed on the use of MODIS-derived NDVI time series data and ground-based estimated statistics-based regression models to enhance the understanding of its forecasting capacity and limitations.

Author Contributions: All authors contributed extensively to the research work presented in this paper. B.M.R.F. comprehensively analyzed and processed the satellite-based research data to find out the outcome of the study and wrote the paper. H.R. conceptualized the research theme and provided instruction in all the process of completing the article. N.H.S., N.S., M.I.I., and T.A. collected relevant ground-based information to validate and investigate the study outcome with necessary corrections at data processing. All the authors discussed the results and implications and commented on the manuscript at all stages of preparing the article.

Funding: This research received no external funding.

Acknowledgments: We would like to thank The National Aeronautics and Space Administration (NASA) for providing the MODIS-derived NDVI data and Bangladesh Bureau of Statistics for providing ground-based estimates to develop model based Boro rice production forecasting estimates. We also would extend our appreciation to Bangladesh Space Research and Remote Sensing Organization (SPARRSO) for technical assistance and service. Noticeably this article has been benefited extremely from the constructive comments of three anonymous expert reviewers and the editorial board.

Conflicts of Interest: The authors declare no conflict of interest.

\section{Appendix}

Table A1. Monthly scale remote sensing regression models for Boro rice production (2011-2017).

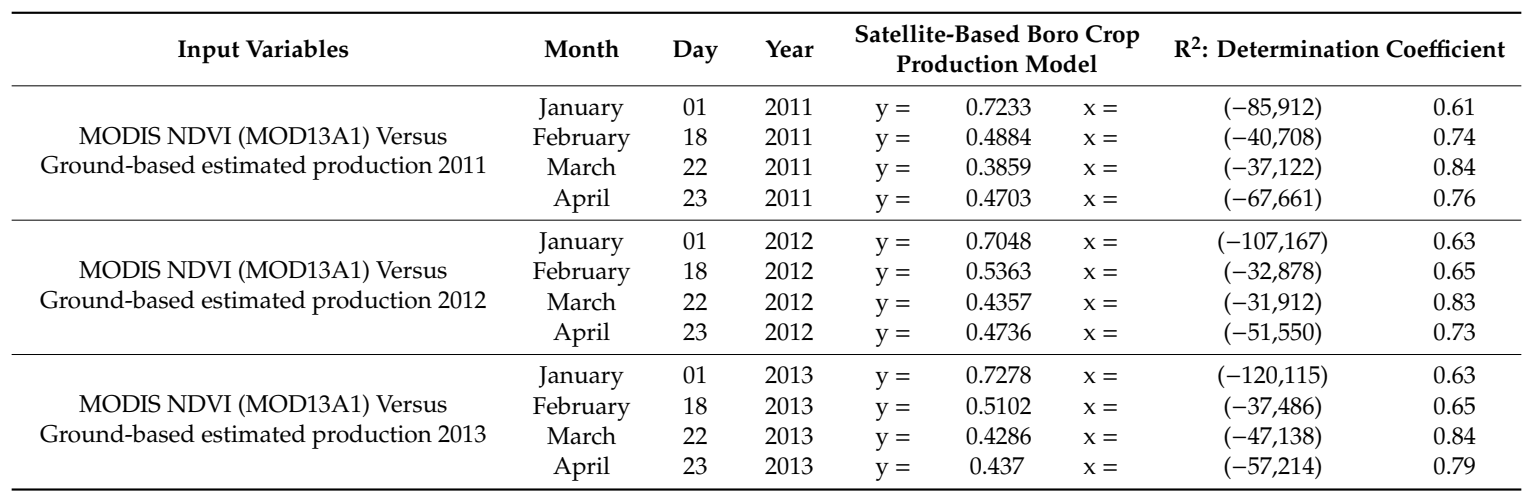


Table A1. Cont.

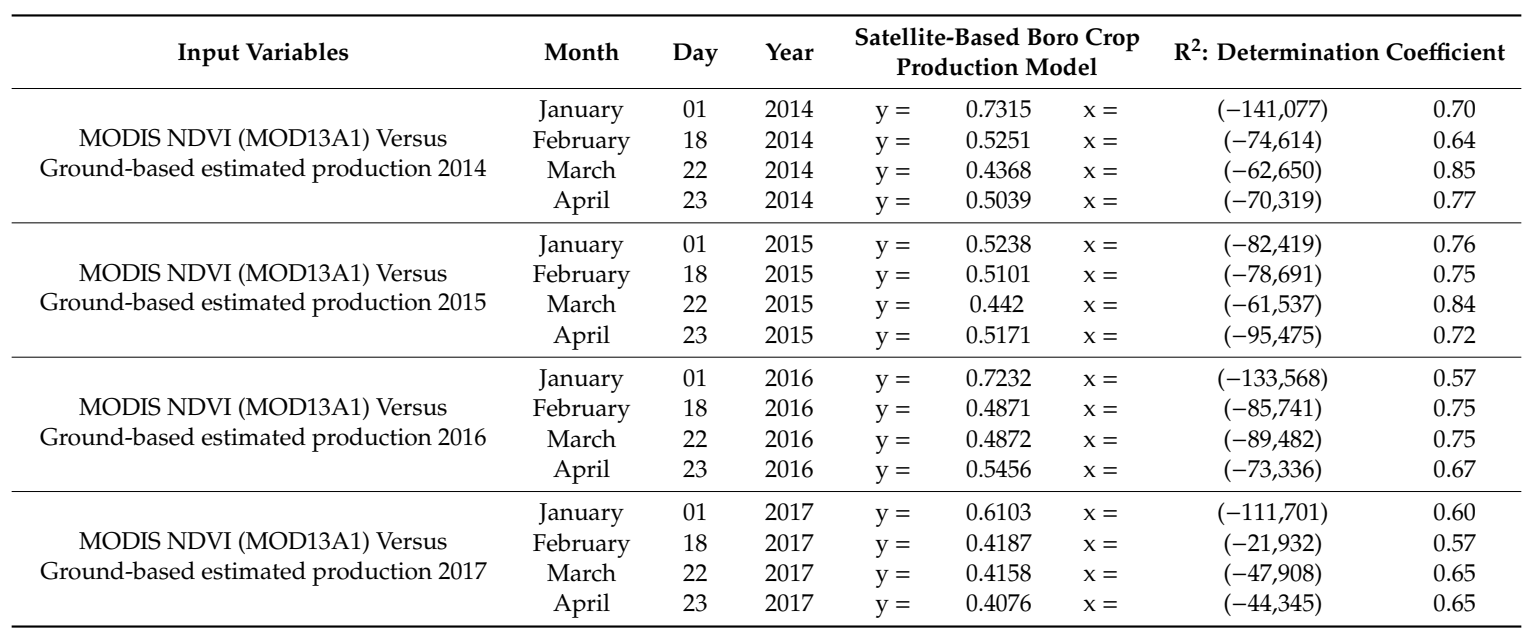

Table A2. RS Model and BBS estimated Boro crop production at yearly scale with statistical analysis.

\begin{tabular}{ccccccc}
\hline \multirow{2}{*}{ Year } & \multicolumn{2}{c}{ Boro Rice Production (M.Ton) } & \multirow{2}{*}{$\mathbf{R}^{2}$} & MBE (M.Ton) & RMSE (M.Ton) & ME \\
\cline { 2 - 4 } & RS Model Estimated & BBS Estimated & & & & \\
\hline 2011 & $18,540,281$ & $19,725,604$ & 0.84 & 19,431 & 10,624 & 0.94 \\
2012 & $18,685,684$ & $16,862,935$ & 0.83 & $-29,881$ & 5238 & 0.92 \\
2013 & $18,718,556$ & $18,186,067$ & 0.84 & -8729 & 9833 & 0.94 \\
2014 & $18,931,747$ & $18,932,353$ & 0.85 & 9 & 9097 & 0.94 \\
2015 & $19,112,340$ & $18,775,269$ & 0.84 & -5525 & 7798 & 0.94 \\
2016 & $18,860,386$ & $17,981,769$ & 0.75 & $-14,403$ & 11,852 & 0.88 \\
2017 & $17,935,857$ & $18,090,556$ & 0.65 & 2536 & 6830 & 0.86 \\
\hline
\end{tabular}

\section{References}

1. Khush, G.S. What it will take to feed 5 billion rice consumers in 2030. Int. J. Mol. Biol. 2005, 59, 1-6. [CrossRef] [PubMed]

2. Muthayya, S.; Sugimoto, J.D.; Montgomery, S.; Maberly, G.F. An overview of global rice production, supply, trade, and consumption. Ann. N. Y. Acad. Sci. 2014, 1324, 7-14. [CrossRef] [PubMed]

3. Purevdorj, M.; Kubo, M. The future of rice production, consumption and seaborne trade: Synthetic prediction method. J. Food Distrib. Res. 2005, 36, 250-259.

4. GeoHive Historic. Current and Future Population: Asia. Available online: http://www.geohive.com/earth/ his_proj_asia.aspx (accessed on 4 April 2017).

5. IPCC. Fifth Assessment Synthesis Report; IPPC: Geneva, Switzerland, 2014; p. 116. Available online: http://www.ipcc. ch/pdf/assessment-report/ar5/syr/SYR_AR5_LONGERREPORT.pdf (accessed on 4 April 2017).

6. World Bank. The Cost of Adapting to Extreme Weather Events in a Changing Climate; Bangladesh Development Series Paper No. 28; World Bank: Washington, DC, USA, 2011; Available online: http://www.worldbank.org. $\mathrm{bd} / \mathrm{bds}$ (accessed on 12 March 2018).

7. Whitcraft, A.K.; Becker-Reshef, I.; Justice, C.O. A framework for defining spatially explicit earth observation requirements for a global agricultural monitoring initiative (GEOGLAM). Remote Sens. 2015, 7, 1461-1481. [CrossRef]

8. Sharman, M.J. The agriculture project of the Joint Research Centre: Operational use of remote sensing for agricultural statistics. In Proceedings of the International Symposium Operationalization of Remote Sensing, 19-23 April 1993; ITC: Enschede, The Netherlands, 1993.

9. De Roover, B.; De Mudker, S.C.; Goossens, R. The regional inventory (MARS) in Belgium. In Proceedings of the International Symposium Operationalization of Remote Sensing, 19-23 April 1993; ITC: Enschede, The Netherlands, 1993.

10. Bastiaanseen, W.G.M.; Ali, S. A new crop yield forecasting model based on satellite measurements applied across the Indus Basin, Pakistan. Agric. Ecosyst. Environ. 2003, 94, 321-340. [CrossRef] 
11. Nuarsa, I.W.; Nishio, F.; Hongo, C. Rice yield estimation using Landsat ETM+ data and field observation. J. Agric. Sci. 2012, 4, 45-56. [CrossRef]

12. Huang, J.; Wang, X.; Li, X.; Tian, H.; Pan, Z. Remotely sensed rice yield prediction using multi-temporal NDVI data derived from NOAA's-AVHRR. PLoS ONE 2013, 8, e70816. [CrossRef]

13. Son, N.T.; Chen, C.F.; Chen, C.R.; Chang, L.Y.; Duc, H.N.; Nguyen, L.D. Prediction of rice crop yield using MODIS EVI-LAI -data in the Mekong Delta, Vietnam. Int. J. Remote Sens. 2013, 34, 7275-7292. [CrossRef]

14. Mosleh, M.K.; Hassan, Q.K.; Chowdhury, E.H. Development of a remote sensing-based rice yield forecasting model. Span. J. Agric. Res. 2016, 14, 0907. [CrossRef]

15. Li, T.; Hasegawa, T.; Yin, X.; Zhu, Y.; Boote, K.; Adam, M.; Bregaglio, S.; Buis, S.; Confalonieri, R.; Fumoto, T.; et al. Uncertainties in predicting rice yield by current crop models under a wide range of climatic conditions. Glob. Chang. Biol. 2015, 21, 1328-1341. [CrossRef]

16. Bangladesh Bureau of Statistics (BBS). Agricultural Census of Bangladesh-2011; Ministry of Planning, Government of the People's Republic of Bangladesh: Dhaka, Bangladesh. Available online: http://www.bbs.gov.bd (accessed on 30 January 2017).

17. Bright, R.M.; Zhao, K.; Jackson, R.B.; Cherubini, F. Quantifying surface surface albedo and other direct biogeophysical climate forcings of forestry activities. Glob. Chang. Biol. 2015, 21, 3246-3266. [CrossRef] [PubMed]

18. Hong, S.; Lakshmi, V.; Small, E.E. Relationship between vegetation biophysical properties and surface temperature using multisensor satellite data. J. Clim. 2007, 20, 5593-5606. [CrossRef]

19. Rahman, S.; Rahman, H.; Keramat, M. Study on the seasonal changes of land cover and their impact on surface albedo in the northwestern part of Bangladesh using remote sensing. Int. J. Remote Sens. 2007, 28, 1001-1022. [CrossRef]

20. Nelson, A.; Boschetti, M.; Manfron, G.; Holecz, F.; Collivignarelli, F.; Gatti, L.; Barbieri, M.L.; Villano, P.; Chandna Setiyono, T. Combining Moderate-Resolution Time-Series RS Data from SAR and Optical Sources for Rice Crop Characterization: Examples from Bangladesh. In Land Applications of Remote Sensing; INTECH-Janeza Trdine 9: 51000 Rijeka, Croatia, Chapter 4; 2014; Available online: http://www.intechopen.com/books/land-applicationsof-radar-remote-sensing (accessed on 20 January 2019).

21. Jing-Feng, H.; Shu-Chuan, T.; Abou-Ismail, O.; Ren-Chao, W. Rice yield estimation using remote sensing and simulation model. J. Zhejiang Univ. Sci. 2002, 3, 461-466. [CrossRef]

22. Chen, C.F.; Son, N.T.; Chang, L.Y.; Chen, C.R. Classification of rice cropping systems by empirical mode decomposition and linear mixture model for time-series MODIS 250m NDVI data in the Mekong Delta, Vietnam. Int. J. Remote Sens. 2011, 32, 5115-5134. [CrossRef]

23. Rahman, A.; Roytman, L.; Krakauer, N.Y.; Nizamuddin, M.; Goldberg, M. Use of vegetation health data for estimation of Aus rice yield in Bangladesh. Sensors 2009, 9, 2968-2975. [CrossRef] [PubMed]

24. Rahman, A.; Khan, K.; Krakauer, N.Y.; Roytman, L.; Kogan, F. Use of remote sensing data for estimation of Aman rice yield. Int. J. Agric. For. 2012, 2, 101-107. [CrossRef]

25. Vien, D. Technology of Remote Sensing in Monitoring Rice Capacity; Publisher of agricultural technique: Beijing, China, 1983. (In Chinese)

26. Dong, J.; Xiao, X.; Menarguez, M.A.; Zhang, G.; Qin, Y.; Thau, D.; Biradar, C.; Moore, B., III. Mapping paddy rice planting area in northeastern Asia with Landsat 8 images, phenology-based algorithm and Google Earth Engine. Remote Sens. Environ. 2016, 185, 142-154. [CrossRef]

27. Tao, F.; Yokozawa, M.; Zhang, Z.; Xu, Y.; Hayashi, Y. Remote sensing of crop production in china by production efficiency models: Models comparisons, estimates and uncertainties. Ecol. Model. 2005, 183, 385-396. [CrossRef]

28. Okamoto, K. Estimation of rice-planted area in the tropical zone using a combination of optical and microwave satellite sensor data. Int. J. Remote Sens. 1999, 20, 1045-1048. [CrossRef]

29. Becker-Reshef, I.; Justice, C.; Sullivan, M.; Vermote, E.; Tucker, C.; Anyamba, A.; Small, J.; Pak, E.; Masuoka, E.; Schmaltz, J.; et al. Monitoring global croplands with coarse resolution earth observations: The global agriculture monitoring (GLAM) project. Remote Sens. 2010, 2, 1589-1609. [CrossRef]

30. Boschetti, M.; Busetto, L.; Manfron, G.; Laborte, A.; Asilo, S.; Pazhanivelan, S.; Nelson, A. PhenoRice: A method for automatic extraction of spatio-temporal information on rice crops using satellite data time series. Remote Sens. Environ. 2017, 194, 347-365. [CrossRef] 
31. Xiao, X.; Boles, S.; Liu, J.; Zhuang, D.; Frolking, S.; Li, C.; Salas, W.; Moore, B., III. Mapping paddy rice agriculture in southern China using multi-temporal MODIS images. Remote Sens. Environ. 2005, 95, 480-492. [CrossRef]

32. Xiao, X.; Boles, S.; Frolking, S.; Li, C.S.; Babu, J.Y.; Salas, W.; Moore, B., III. Mapping paddy rice agriculture in South and Southeast Asia using multi-temporal MODIS images. Remote Sens. Environ. 2006, 100, 95-113. [CrossRef]

33. Zhang, G.; Xiao, X.; Biradar, C.M.; Dong, J.; Qin, Y.; Menarguez, M.A.; Zhou, Y.; Zhang, Y.; Jin, C.; Wang, J.; et al. Spatiotemporal patterns of paddy rice croplands in China and India from 2000 to 2015. Sci. Total Environ. 2015, 579, 82. [CrossRef] [PubMed]

34. Reynolds, C.A.; Yitayew, M.; Slack, D.C.; Hutchison, C.F.; Huete, A.; Petersen, M.S. Estimating crop yields and production by integrating the FAO crop specific water balance model with real-time satellite data and ground based ancillary data. Int. J. Remote Sens. 2000, 21, 3487-3508. [CrossRef]

35. Prasad, A.K.; Chai, L.; Singh, R.P. Crop yield estimation model for Iowa using remote sensing and surface parameters. Int. J. Appl. Earth Obs. Geoinf. 2006, 8, 26-33. [CrossRef]

36. Nguyen, L.D.; Phung, H.P.; Huth, J.; Phung, C.V. Estimation of the rice yield in the Mekong Delat using dual polarisationTerraSAR-X data. VNU J. Sci. Earth Environ. Sci. 2012, 28, 20-28.

37. Noureldin, N.A.; Aboelghar, M.A.; Saudy, H.S.; Ali, A.M. Rice yield forecasting models using satellite imagery in Egypt. Egypt. J. Remote Sens. Space Sci. 2013, 16, 125-131. [CrossRef]

38. Bala, S.K.; Islam, A.S. Correlation between potato yield and MODIS-derived vegetation indices. Int. J. Remote Sens. 2009, 30, 2491-2507. [CrossRef]

39. Mosleh, M.K.; Hassan, Q.K. Development of a remote sensing-based “Boro" rice mapping system. Remote Sens. 2014, 6, 1938-1953. [CrossRef]

40. Wiegand, C.L.; Rechardson, A.J.; Escobar, D.E.; Gerbermann, A.H. Vegetation indices in crop assessment. Remote Sens. Environ. 1990, 35, 105-119. [CrossRef]

41. Tucker, C.J. Red and photosynthetic infrared linear combination for monitoring vegetation. Remote Sens. Environ. 1979, 8, 127-150. [CrossRef]

42. Holben, B.N.; Tucker, C.J.; Fan, C.J. Spectral assessment of soybean leaf area and leaf biomass. Photogramm. Eng. Remote Sens. 1980, 46, 651-656.

43. Ahlrichs, J.S.; Bauer, M.E. Relation of agronomic and multispectral reflectance characteristics of spring wheat canopies. Agron. J. 1983, 75, 987-993. [CrossRef]

44. Nemani, R.R.; Running, S.W. Testing a theoretical climate-soil leaf area hydrological equilibrium of forests using satellite data and ecosystem simulation. Agric. For. Meteorol. 1989, 44, 245-260. [CrossRef]

45. Boschetti, M.; Stroppiana, D.; Brivio, P.A.; Bocchi, S. Multi-year monitoring of rice crop phenology through time series analysis of MODIS images. Int. J. Remote Sens. 2009, 30, 4643-4662. [CrossRef]

46. Colombo, R.; Busetto, L.; Fava, F.; Di Mauro, B.; Migliavacca, M.; Cremonese, E.; Galvagno, M.; Rossini, M.; Meroni, M.; Cogliati, S.; et al. Phenological monitoring of grassland and larch in the Alps from Terra and Aqua MODIS images. Ital. J. Remote Sens. 2011, 43, 83-96. [CrossRef]

47. Hmimina, G.; Dufrene, E.; Pontailler, J.Y.; Delpierre, N.; Aubinet, M.; Caquet, B.; de Grandcourt, A.; Burban, B.; Flechar, C.; Granier, A.; et al. Evaluation of the potential of MODIS satellite data to predict vegetation phenology in different biomes: An investigation using ground-based NDVI measurements. Remote Sens. Environ. 2013, 132, 145-158. [CrossRef]

48. Soudani, K.; Francois, C.; le Maire, G.; Le Dantec, V.; Dufrene, E. Comparative analysis of IKONOS, SPOT, and ETM+ data leaf area index estimation in temperature coniferous and deciduous forest stands. Remote Sens. Environ. 2006, 102, 161-175. [CrossRef]

49. Sesnie, S.E.; Dickson, B.G.; Rosenstock, S.S.; Rundall, J.M. A comparison of Landsat TM and MODIS vegetation indices for estimating forage phenology in desert bighorn sheep (Oviscanadensisnelsoni) habitat in the Sonoran Desert, USA. Int. J. Remote Sens. 2012, 33, 276-286. [CrossRef]

50. Salam, M.A.; Rahman, H. Application of remote sensing and geographic information system (GIS) techniques for monitoring boro rice expansion area in Bangladesh. Asian J. Geoinf. 2014, 14, 11-17.

51. Shiu, Y.; Lin, M.; Huang, C.; Chu, T. Mapping paddy rice agriculture in a highly fragmented area using a geographic information system object-based post classification process. J. Appl. Remote Sens. 2012, 6, 063526.

52. Amhed, A.U. Bangladesh: Climate Change Impacts and Vulnerability A Synthesis; Climate Change Cell, Department of Environment: Dhaka, Bangladesh, 2006; ISBN 984-32-3467-7. 
53. Master Planning Organization (MPO). National Water Management Plan: Phase II; Final Report-1991; Ministry of Irrigation, Water Development and Flood Control, Government of the People's Republic of Bangladesh: Dhaka, Bangladesh, 1991.

54. FAO. Rice: Post-harvest Operations; Food and Agriculture Organization (FAO) of United Nations, International Rice Research Institute: Los Baños, Philippines, 1999.

55. IRRI. The international Rice Research Institute (IRRI) Rice Facts; IRRI: Los Banos, Philippines, 1997.

56. Shahid, S.; Wang, X.; Rahman, M.M.; Hasan, R.; Harun, S.B.; Shamsudin, S. Spatial Assessment of Groundwater Over-exploitation in Northwestern Districts of Bangladesh. J. Geol. Soc. India 2015, 85, 463-470. [CrossRef]

57. Didan, K. MOD13A1: MODIS/Terra Vegetation Indices 16-Day L3 Global 500m SIN Grid V006; NASA EOSDIS LP DAAC: Sioux Falls, SD, USA, 2015.

58. Didan, K.; Munoz, A.B.; Solano, R.; Huete, A. MODIS Vegetation Index User's Guide (MOD13 Series); Version 3.00; Vegetation Index and Phenology Lab, The University of Arizona: Tucson, Arizona, 2015; Available online: http://vip.arizona.edu (accessed on 25 July 2019).

59. Gao, X.; Huete, A.R.; Ni, W.; Miura, T. Optical-biophysical relationships of vegetation spectra without background contamination. Remote Sens. Environ. 2000, 74, 609-620. [CrossRef]

60. Huete, A.; Didan, K.; Miura, T.; Rodriguez, E.P.; Gao, X.; Ferreira, L.G. Overview of the radiometric and biophysical performance of the MODIS vegetation indices. Remote Sens. Environ. 2002, 83, 195-213. [CrossRef]

61. Bangladesh Bureau of Statistics (BBS). Statistical Pocketbook of Bangladesh-2016; Government of the People's Republic of Bangladesh: Dhaka, Bangladesh, 2017. Available online: http://www.bbs.gov.bd (accessed on 21 January 2019).

62. Bangladesh Bureau of Statistics (BBS). Yearbook of Agricultural Statistics-2016; 28th Series; May 2017; Statistics and Informatics Division (SID), Ministry of Planning, Government of the People's Republic of Bangladesh: Dhaka, Bangladesh, 2017. Available online: http://www.bbs.gov.bd (accessed on 21 January 2019).

63. Eidenshink, J.C.; Faundeen, J.L. The 1-km AVHRR global land data set: First stages in implementation. Int. J. Remote Sens. 1994, 15, 3443-3462. [CrossRef]

64. Holben, B.N. Characteristics of maximum-value composite images from temporal AVHRR data. Int. J. Remote Sens. 1986, 7, 1417-1434. [CrossRef]

65. Wim, J.D.; Leeuwen, V.; Huete, A.R.; Laing, T.W. MODIS Vegetation Index Compositing Approach: A Prototype with AVHRR Data. Remote Sens. Environ. 1999, 69, 264-280.

66. Chuvieco, E.; Ventura, G.; Martin, M.P.; Gomez, I. Assessment of multitemporal compositing techniques of MODIS and AVHRR images for burned land mapping. Remote Sens. Environ. 2005, 94, 450-462. [CrossRef]

67. Chen, D.; Stow, D.A.; Gong, P. Examining the effect of spatial resolution and texture window size on classification accuracy: An urban environment case. Int. J. Remote Sens. 2004, 25, 1-16. [CrossRef]

68. Markham, B.L.; Townshend, J.R.G. Land cover classification accuracy as a function of sensor spatial resolution. In Proceedings of the 15th International Symposium on Remote Sensing of Environment, Ann Arbor, MI, USA, 11-15 May 1981; pp. 1075-1090.

69. Marceau, D.J.; Howarth, P.J.; Gratton, D.J. Remote Sensing and the measurement of Geographical Entities in a forest environment 1: The scale and spatial aggregation problem. Remote Sens. Environ. 1994, 49, 93-104. [CrossRef]

70. Marceau, D.J.; Howarth, P.J.; Gratton, D.J. Remote Sensing and the measurement of Geographical Entities in a forest environment 2, the optimal spatial resolution. Remote Sens. Environ. 1994, 49, 105-117. [CrossRef]

71. Earth Resources Data Analysis System (ERDAS) IMAGINE Essentials ${ }^{\text {TM }}$ Tour Guides 2017; Technical Documentation ERDAS, Inc.: Norcross, GA, USA, 2017.

72. Gat, N.; Erives, H.; Fitzegerald, G.J.; Kaffka, S.R.; Mass, S.J. Estimate Sugar Beet Yield Using AVIRIS-Derived Indices. 2000. Available online: http://makalu.jpl.nasa.gov/docs/workshops/00_docs/Gat_web.pdf (accessed on 18 September 2007).

73. Liu, W.T.; Kogan, F. Monitoring Brazilian soybean production using NOAA/AVHRR based vegetation condition indices. Int. J. Remote Sens. 2002, 23, 1161-1179. [CrossRef]

74. Nessa, M. Monitoring of Rice Growth and Production in Bangladesh Using NOAA Satellite Data; Bangladesh University of Engineering and Technology: Dhaka, Bangladesh, 2004. 
75. Haig, L.A.S. Crop Yield Estimation: Integrating RS, GIS and Management Factors; International Institute for Geo-Information Science and Earth Observation: Enschede, The Netherlands, 2003.

76. Murthy, C.S.; Jonna, S.; Raju, P.V.; Thurivengadachari, S.; Hakeem, K.A. Crop Yield Prediction in Command Area Using Satellite Data. 1994. Available online: http://www.gisdevelopment.net/aars/acrs/1994/ps1/ ps1014pf.htm (accessed on 24 August 2007).

77. Boken, V.K.; Shaykewich, C.F. Improving an operational wheat yield model using phenological phase-based Normalized Difference Vegetation Index. Int. J. Remote Sens. 2002, 23, 4155-4168. [CrossRef]

78. Rojas, O. Operational maize yield model development and validation based on remote sensing and agro-meteorological data in Kenya. Int. J. Remote Sens. 2007, 28, 3775-3793. [CrossRef]

79. Doraiswamy, P.C.; Cook, P.W. Spring wheat yield assessment using NOAA AVHRR data. Can. J. Remote Sens. 1995, 21, 43-51. [CrossRef]

80. Benedetti, R.; Rossini, P. On the use of NDVI profiles as a tool for agricultural statistics: The case study of wheat yield estimate and forecast in Emilia Romagna. Remote Sens. Environ. 1993, 45, 311-326. [CrossRef]

81. Tucker, C.J.; Holben, B.N.; Elgin, J.H.; McMurtrey, J.E. Relationship of spectral data to grain yield variation. Photogrammetric Engineer. Remote Sens. 1980, 46, 657-666.

82. Nuarsa, I.W.; Nishio, F.; Hongo, C. Relationship between rice spectral and rice yield using MODIS data. J. Agric. Sci. 2011, 3, 80-88. [CrossRef]

83. Siyal, A.A.; Dempewolf, J.; Becker-Reshef, I. Rice yield estimation using Landsat ETM_Data. J. Appl. Remote Sens. 2015, 9, 095986. [CrossRef]

84. Willmott, C.J. Some comments on the evaluation of model performance. Bull. Am. Meteorol. Soc. 1982, 63, 1309-1313. [CrossRef]

85. Chai, T.; Draxler, R.R. Root mean square error (RMSE) or mean absolute error (MAE)?-Arguments against avoiding RMSE in the literature. Geosci. Model Dev. 2014, 7, 1247-1250. [CrossRef]

86. Fuller, D.O. Trends in NDVI time series and their relation to rangeland and crop production in Senegal, 1987-1993. Int. J. Remote Sens. 1998, 19, 2013-2018. [CrossRef]

87. Mkhabela, M.S.; Bullock, P.; Raj, S.; Wang, S.; Yang, Y. Crop yield forecasting on the Canadian prairies using MODIS NDVI data. Agric. For. Meteorol. 2011, 151, 385-393. [CrossRef]

88. Shew, A.M.; Ghosh, A. Using multi-temporal remote sensing data to analyze the spatio-temporal patterns of dry season rice production in Bangladesh. In Proceedings of the 2nd International Symposium on Spatiotemporal Computing, ISPRS Annals of the Photogrammetry, Remote Sensing and Spatial Information Sciences, Cambridge, MA, USA, 7-9 August 2017; Volume IV-4/W2. [CrossRef]

89. Mosleh, M.K.; Hassan, Q.K.; Chowdhury, E.H. Application of remote sensors in mapping rice area and forecasting its production: A review. Sensors 2015, 15, 769-791. [CrossRef] [PubMed]

90. Wang, Y.P.; Chang, K.W.; Chen, R.K.; LO, J.C.; Shen, Y. Large-area rice yield forecasting using satellite imageries. Int. J. Appl. Earth Obs. Geoinf. 2010, 12, 27-35. [CrossRef]

91. Rapsomanikis, G. The Economic Lives of Smallholder Farmers: An Analysis Based on Household Data from Nine Countries; Food and Agricultural Organization (FAO) of the United Nations: Rome, Italy, 2015.

92. Boschetti, L.; Flasse, S.P.; Brivio, P.A. Analysis of the conflict between omission and commission in low spatial resolution dichotomic thematic products: The Pareto Boundary. Remote Sens. Environ. 2004, 91, 280-292. [CrossRef]

93. Savin, I.Y.; Isaev, V.A. Rice yield forecast based on satellite and meteorological data. Russ. Agric. Sci. 2010, 36, 424-427. [CrossRef]

(C) 2019 by the authors. Licensee MDPI, Basel, Switzerland. This article is an open access article distributed under the terms and conditions of the Creative Commons Attribution (CC BY) license (http://creativecommons.org/licenses/by/4.0/). 